University of Nebraska - Lincoln

DigitalCommons@University of Nebraska - Lincoln

$1-8-2014$

\title{
HYPENA OPULENTA (EREBIDAE): A EUROPEAN SPECIES FOR THE BIOLOGICAL CONTROL OF INVASIVE SWALLOW-WORTS (VINCETOXICUM SPP.) IN NORTH AMERICA
}

Jim Young

United States of America Department of Agriculture, jim.d.young@aphis.usda.gov

Aaron S. Weed

Dartmouth College, Hanover, aaron.s.weed@dartmouth.edu

Follow this and additional works at: https://digitalcommons.unl.edu/usdaarsfacpub

Young, Jim and Weed, Aaron S., "HYPENA OPULENTA (EREBIDAE): A EUROPEAN SPECIES FOR THE BIOLOGICAL CONTROL OF INVASIVE SWALLOW-WORTS (VINCETOXICUM SPP.) IN NORTH AMERICA" (2014). Publications from USDA-ARS / UNL Faculty. 2339.

https://digitalcommons.unl.edu/usdaarsfacpub/2339

This Article is brought to you for free and open access by the U.S. Department of Agriculture: Agricultural Research Service, Lincoln, Nebraska at DigitalCommons@University of Nebraska - Lincoln. It has been accepted for inclusion in Publications from USDA-ARS / UNL Faculty by an authorized administrator of DigitalCommons@University of Nebraska - Lincoln. 
Journal of the Lepidopterists' Society

$68(3), 2014,162-166$

\title{
HYPENA OPULENTA (EREBIDAE): A EUROPEAN SPECIES FOR THE BIOLOGICAL CONTROL OF INVASIVE SWALLOW-WORTS (VINCETOXICUM SPP.) IN NORTH AMERICA
}

\author{
Jim Young, PhD. \\ United States of America Department of Agriculture, Animal and Plant Health Inspection Service, Plant Protection and Quarantine. \\ 2400 Broening Hwy. Ste 102, Baltimore, MD 21124. jim.d.young@aphis.usda.gov
}

AND

Aaron S. WEED

Department of Biological Sciences, Dartmouth College, Hanover, NH 03755, aaron.s.weed@dartmouth.edu

\begin{abstract}
The moth Hypena opulenta (Christoph, 1877) (Lepidoptera: Erebidae) was approved for release in eastern Canada and is pending approval in the United States of America as a biological control agent of the invasive European swallow-worts (Vincetoxicum spp.). Descriptions of the adult in Noctuidae Europeae do not accurately represent the color morph of the rearing colony so a new description is provided. Also for the first time the larva is described and illustrated and a simple key is provided that separates H. opulenta from most of the Hypena spp. in the Northeastern U.S.
\end{abstract}

Additional key words: swallow-worts, Vincetoxicum, biological control, larva, adult

Swallow-worts, (Vincetoxicum spp.), were introduced from Europe to northeastern North America as ornamentals in the mid-19th century. Two species, Vincetoxicum nigrum (L.) Moench and V. rossicum (Kleopow) Barbar. are both considered invasive in several U.S. states and two Canadian provinces. Vincetoxicum nigrum (black swallow-wort) is widely distributed in the United States with populations recorded from 21 states (USA: CA, CT, IL, IN, KS, KY, MA, MD, ME, MI, MN, MO, NE, NH, NJ, NY, OH, PA, RI, VT, WI) and 2 Canadian provinces (ON, QC) (DiTommaso et al. 2005, USDA NRCS 2013). V. rossicum (pale swallow-wort or dog-strangling vine) is established in nine states (CT, IN, MA, MI, MO, NH, NJ, NY, PA) and 3 Canadian provinces (BC, ON, QC) (DiTommaso et al. 2005, USDA NRCS 2013). Vermont (USA) and Ontario (CAN) have designated both species as noxious weeds (DiTommaso et al. 2005). Casagrande and Dacey (2007) found that in eastern North America the monarch butterfly Danaus plexippus (L.) commonly mistakes $V$. nigrum as a host and in some areas lays about $15 \%$ of its eggs on V. nigrum when Asclepias hosts are present. This is a costly mistake that accounts for considerable mortality for monarchs.

The native distribution of $H$. opulenta (Christoph, 1877) extends from Russia, east to Afghanistan, and south into Iran and Syria (Fibiger et al. 2010). In 2006, $H$. opulenta was collected from $V$. rossicum and the sympatric species $V$. scandens (Sommier et Levier) Pobed. in forested sites located in southeast Ukraine. Adult $H$. opulenta moths emerge in the spring, mate, and oviposit on the undersides of leaves or in grooves along petioles. Larvae preferentially feed on newly expanding leaves and complete five instars before either pupating in the soil or in tied-up leaves (Weed and Casagrande 2010). Pupal diapause is facultative and at least two generations per year are possible (Fibiger et al. 2010, Weed and Casagrande 2010). Based upon observed defoliation of Vincetoxicum (Weed et al. 2011), the potential for significant negative impact to the growth and reproduction of $V$. rossicum (Weed and Casagrande 2010), and demonstrated feeding specificity to the genus Vincetoxicum (Hazlehurst et al. 2012), a petition was submitted to Technical Advisory Group for Biological Control Agents of Weeds (TAG) in 2011 for conducting field releases in the U.S. Additional information was requested in early 2013 and in August 2013 TAG completed its review of the petition and wrote a letter to the United States Department of Agriculture (USDA) Animal and Plant Health Inspection Service (APHIS) recommending them to approve the release of $H$. opulenta. USDA APHIS Plant Protection and Quarantine (PPQ) reviewed the petition and supporting documents and contacted the Principal Investigators and suggested they submit an "Application For Permit To Move Live Plant Pests or Noxious Weeds" (PPQ Form 526). Once submitted the expected timeline for a final decision is greater than one year. The Canadian government approved field releases in Summer of 2013 and a release was conducted in Ottawa $(\mathrm{ON})$. If this introduction is successful adults may be encountered as early as the spring of 2014 in the areas surrounding Ottawa Canada.

The typical color morphs of the H. opulenta currently in quarantine, however do not match Fibiger's (2010) description of the adult wing pattern and coloration. 


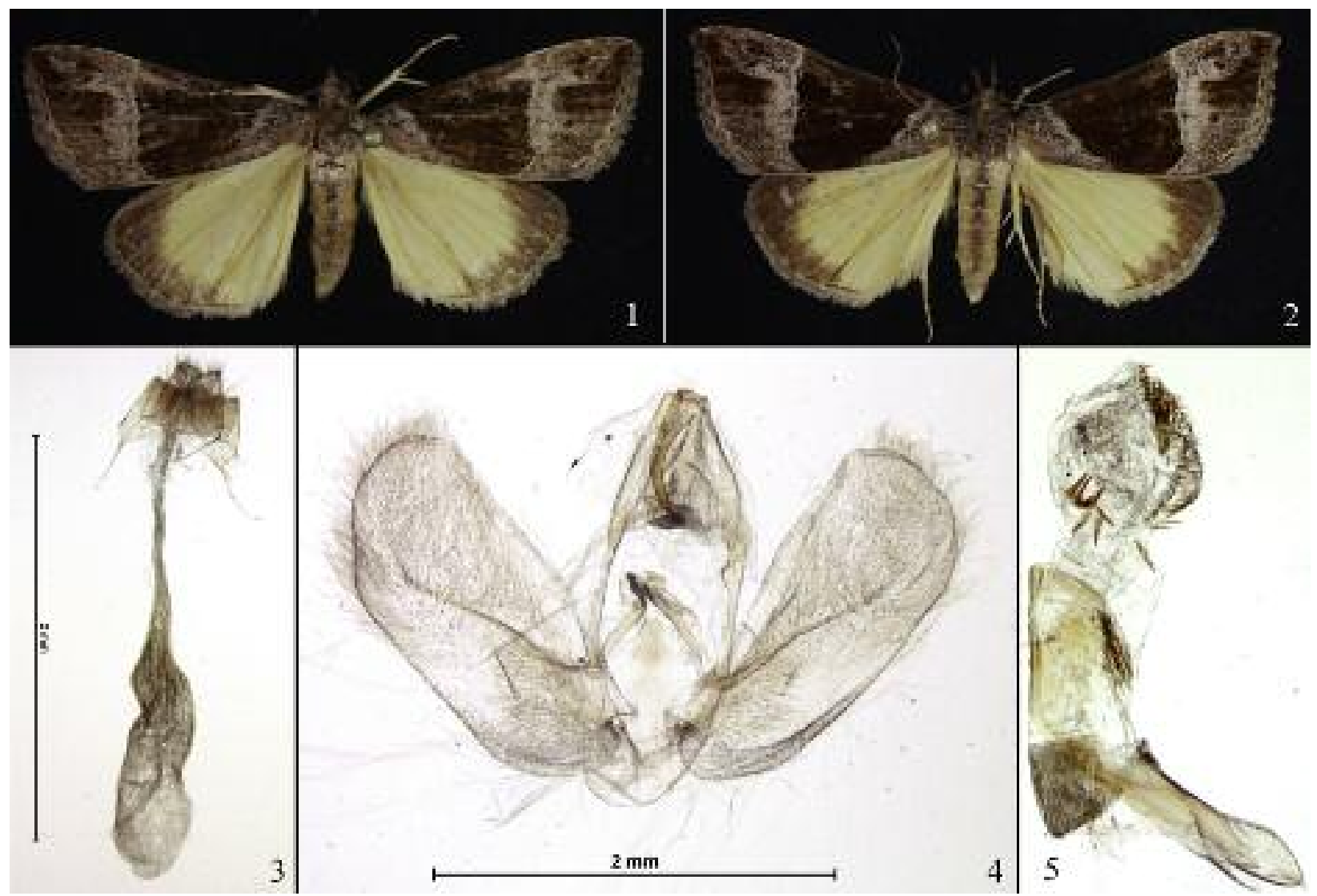

Fig. 1-5: Hypena opulenta. 1: adult female, 2: adult male, 3: female genitalia, 4: male genitalia, 5: male aedaegeus

This could be due to geographical differences unknown by Fibiger or an artifact of establishing breeding colonies from a small number of individuals which has resulted in a genetic bottleneck (Frankham 1995). Additionally, the endophallus presented in Fibiger was not fully extended and the large basal cornuti are largely obscured.

Due to these differences, and the relative inaccessibility of Fibiger (2010) to the layperson, adult H. opulenta descriptions are provided to assist with the identification. The larva of $H$. opulenta is described and illustrated for the first time. In addition a screening aid is provided for researchers and the layperson in the field to separate $H$. opulenta for many of the common native Hypena sp. in the eastern U.S. and Canada. (McCabe and Vargas 1998, Wagner et al. 2011). Images of the male and female pupae are also provided.

\section{Methods}

Examined specimens originated from a population that was collected near Donetsk, Ukraine in 2006. The lab colony was started from four pupae that were removed from tied leaves of $\mathrm{V}$. rossicum in a forested ravine ( $\mathrm{N} 47^{\circ} 34.497^{\prime} \mathrm{E} 37^{\circ} 46.168^{\prime}$ ) along with 32 larvae collected on $V$. rossicum and $V$. scandens within a nearby forest ( $\mathrm{N} 47^{\circ} 48.681^{\prime} \mathrm{E} 38^{\circ} 32.738^{\prime}$ ) (Weed et al. 2011). Specimens were transported to the laboratory at CABI EU- Switzerland (Delémont, Switzerland) and then transferred to the insect quarantine facility at the University of Rhode Island, Kingston, RI, USA where a research colony is maintained on $V$. nigrum, $V$. rossicum, and V. hirundinaria (L.) Pers. A few adults that emerged from field-collected material were frozen and then shipped to Dr. Michael Fibiger (Denmark) for species identification.

Genitalia were prepared by gently heating the removed abdomens in a $10 \%$ solution of $\mathrm{KOH}$ for 12-15 minutes and then mechanically extracting the genitalia from the abdomen using ultra-fine forceps. Debris was then removed using a size 00 camel hair brush. Terminology for wing markings and genital structures follows Lafontaine (1987). Images of the, adults, genitalia, and pupae were taken using Nikon SMZ1500 stereo microscope with a Nikon DS-Fil camera. Larval drawings were hand rendered and images were digitally finalized and colored using Adobe Photoshop Elements ver. 10. The image of the live larva was taken with a Canon Powershot S2 IS. 


\section{MORPHOLOGY}

Adult. (Fig 1 \& 2) Males and females are similar in appearance with females being slightly more drab, however this difference was less obvious on rubbed adults. Both genders are approximately the same size with a forewing length averaging $15 \mathrm{~mm}$ (range 14 to 17 $\mathrm{mm}$ ). Head of male and female antenna simple; palps elongated. Dorsum of the thorax with erect brown setae otherwise unmarked. Dorsal forewing with slightly pointed distal tip, brown to very dark brown with gray to cream colored markings; basal line slanted to the apical $2 / 3$ of the anterior margin towards the body and the area between it and the body entirely light in color; postmedial line straight, light in color and coalescing with the apical patch and inner angle; subterminal line present and light in color, often fusing with lightly colored areas of the apex and inner angle; terminal lunules dark and strongly contrasting the subterminal line and pale fringe. Dorsal hindwing is pale yellow with a distal brown band that is wide at the anterior margin and becoming narrower and is obsolete by the tornus; outer margin of the wing with short white fringe. Dorsum of the abdomen with a poorly defined medial stripe of dark brown scale like setae, otherwise covered with light brown hairs. Coloration of the hindwing alone separates this species from all other North American species of Hypena. Unspread and live specimens most closely resemble $H$. vetustalis and $H$. eductalis. For differences and variation of native Hypena spp. wing patterns see Moth Photographers Group (2013) and Rings et al. (1992).

Female genitalia (Fig 3) with papillae anneles short and not well differentiated; subbasal setae long and forming a dense collar; posterior apophasis slender and not surpassing the anterior apophysis which are short; ductus bursae elongate, unsclerotized; corpus bursae elongate, sclerotized proximally and without signa. Male genitalia (Fig $4 \& 5$ ) with broad valves and distal tip with a weak broad hook; saccus thickened, short and broad; clavus well developed with proximal edge concave; clasper reduced to a fold; aedeagus short and well sclerotized; basal end turned nearly 45 degrees from distal end; inflated vesica (or endophallus) is short, approximately same length as aedeagus, with distal end capitate, the base of the capitate swelling with six dorsal and three ventral well developed cornuti, ventral surface of the distal end of the vesica with a broad and dense field of fleshy spines.

Larva. (Figs $6 \& 7$ ) Fully grown larvae are 14 to 22 $\mathrm{mm}$ in length, green (Fig. 6) and with all major setae of head and body with dark well defined setal bases except those of SV2 of abdominal segments 5 and 6 (Fig. 7).

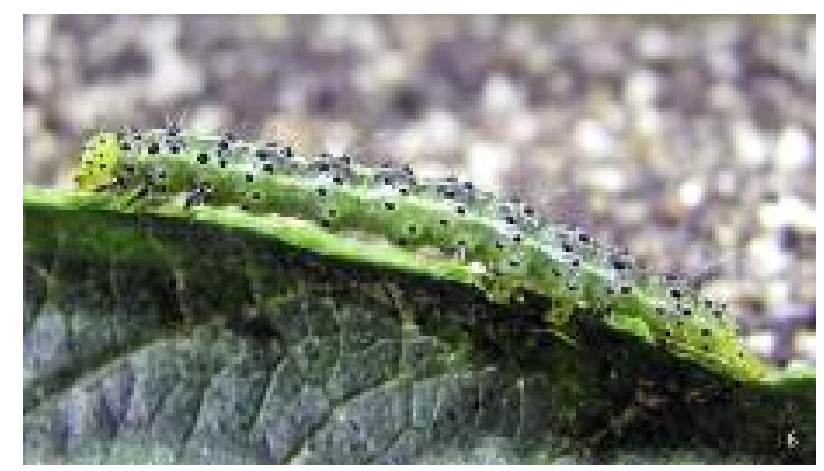

Fig. 6. Live Hypena opulenta larva

Head is smooth and with all major and minor setae with dark bases, mandible with dorsal portion blade like and ventral half with 3 well-formed teeth. The thorax is typical of most Hypena spp. in that the prothoracic shield is not developed. Meso- and metathorax with setal bases of D1 \& D2 fused to form a double peaked chalazae. Abdominal segments with D and SD setal bases conical (chalazae). Abdomen with segment 1 with dark mark not associated with any setae dorsal of the spiracle, on abdominal segments $2-8$ this mark is anterior of the spiracle, segment 3 without a proleg, prolegs on 4, 5, and 6 each with 22-30 crochets.

The following screening aid was created to separate this species from most of the species in the Northeastern U.S. and a few species from outside that range. The aid takes into consideration the follow species; H. abalienalis, $H$. baltimoralis, $H$. bijugalis, $H$. deceptalis, $H$. edictalis, $H$. eductalis, $H$. humuli, $H$. madefactalis, H. manalis, H. palparia, H. scabara, and H. sordidula (McCabe and Vargas 1998, Moth Photographers Group 2013, Wagner et al. 2011). Larvae of $H$. appalachiensis, H. minualis, and H. atomaria are either not known or described in sufficient detail and where not available at the time of writing.

Screening aid to separate late instar Hypena opulenta from common species of Hypena found in the Eastern US.

\begin{tabular}{|c|c|c|}
\hline & $\begin{array}{l}\text { Abdominal segment } 3 \text { with pair of } \\
\text { obvious prolegs }\end{array}$ & Not H. opulenta \\
\hline & $\begin{array}{l}\text { Abdominal segment } 3 \text { without a pair of } \\
\text { obvious functional prolegs }\end{array}$ & 2 \\
\hline 2 & $\begin{array}{l}\text { D setal bases on A9 light or concolorous } \\
\text { with the integument }\end{array}$ & Not H. opulenta \\
\hline & $\begin{array}{l}\text { D setal bases on A9 dark, strongly } \\
\text { contrasting the color of the integument }\end{array}$ & 3 \\
\hline 3 & $\begin{array}{l}\text { D setal bases on A9 flat or slightly raised, } \\
\text { small and distinctly separated }\end{array}$ & Not H. opulenta \\
\hline & $\begin{array}{l}\text { D setal bases on A9 conical, large, and } \\
\text { nearly touching }\end{array}$ & Probably H. opulenta \\
\hline
\end{tabular}




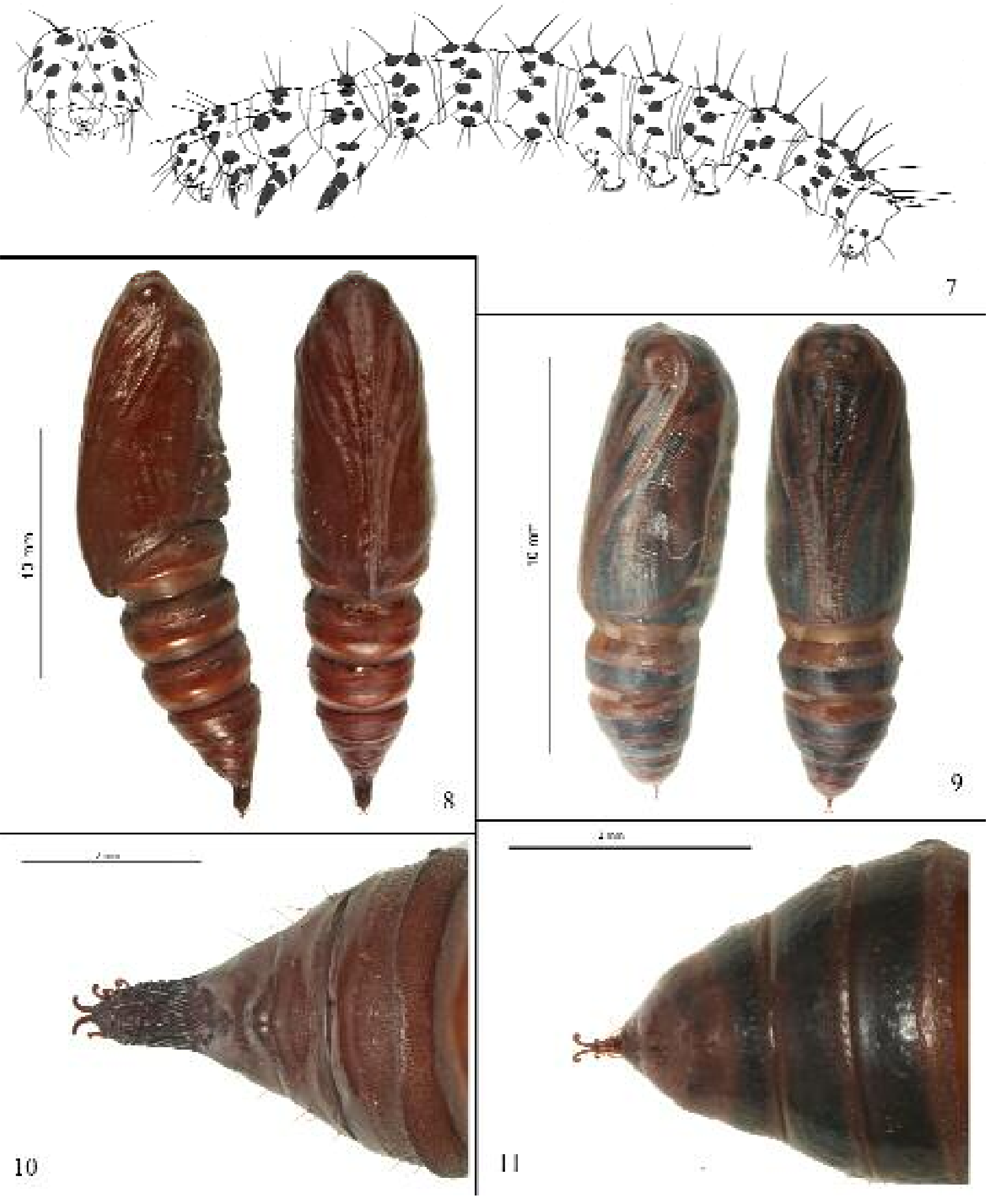

Fig. 7-11: Hypena opulenta. 7: anterior view of head and lateral view of the last instar larva, 8:lateral and ventral views of female pupa, 9: lateral and ventral views male pupa, 10: terminal segments of female pupa, 11: terminal segments of male pupa 
Pupa. (Figs 8-11) Images of the general habitus and of the terminal segments are provided for direct comparison to pupae found on or near Vincetoxicum spp. Descriptions or detailed illustrations of North American Hypena spp. pupae are not available for comparison.

\section{ACKNOWLEDGMENTS}

We thank Volodymyr Ostapko for his assistance during collections in Ukraine and Richard Casagrande, Lisa Tewksbury, members of the University of Rhode Island Biological Control Laboratory (Kingston, RI) for their assistance with rearing and measurements, Dr. Steven Passoa of United States Department of Agriculture- Animal and Plant Health Inspection Service for his technical expertise, and Eric H. Metzler and an anonymous reviewer for their time and expertise. Financial support provided by the United States Department of Agriculture- Forest Service and the Northeastern IPM program and United States Department of Agriculture- Animal and Plant Health Inspection Service- Plant Protection and Quarantine -Baltimore. This material was made possible, in part, by a Cooperative Agreement from the United States Department of Agriculture's Animal and Plant Health Inspection Service (APHIS). It may not necessarily express APHIS' views.

\section{Literature CiteD}

Casagrande, R. \& J. Dacey. 2007 Monarch Butterfly Oviposition on Swallow-Worts (Vincetoxicum spp.). Environ. Entomol. 36: 63136.

DiTommaso, A., F. LaWlor, and S. J. Darbyshire. 2005. The Biology of Invasive Alien Plants in Canada. 2. Cynanchum rossicum (Kleopow) Borhidi [= Vincetoxicum rossicum (Kleopow) Barbar.] and Cynanchum louiseae (L.) Kartesz \& Gandhi [= Vincetoxicum nigrum (L.) Moench]. Can J. Plant Res. 85:243-263.
Fibiger, M., L. Ronkay, J. Yela, and A. Zilli. 2010. Noctuidae Europaeae. Vol. 12. Rivulinae-Phytometrinae, and Micronoctuidae, including Supplement to Noctuidae Europaeae. Vols 1-11. Entomol. Press, Sorø. $450 \mathrm{pp}$

Frankham, R. (1995). Conservation genetics. Ann. Rev. Genetics, 29: 305-327.

Hazlehurst, A. F., A. S. Weed, L. Tewksbury, and R. A. Casagrande. 2012. Host specificity of Hypena opulenta: a potential biological control agent of Vincetoxicum in North America. Environ. Entomol. 41:841-848.

Lafontaine, J.D. 1987. The Moths of North America North of Mexico. Fascicle 27.2. Noctuoidea Noctuidae (Part). The Wedge Entomological Foundation, Washington, $237 \mathrm{pp}$.

McCabe, T. L., AND V. Vargas. 1998. The larva of Hypena manalis (Lepidoptera: Noctuidae: Hypeninae). J. New York Entomol. Soc.. 106:109-113.

Мотн Рнотоgraphers Group. http://mothphotographersgroup. msstate.edu/. Accessed 11/27/2013

Rings, R.W., E.H. Metzler, F. J. Arnold, and D.H. Harris. 1992. The Owlet Moths of Ohio, Order Lepidoptera Family Noctuidae. Bull. Ohio Biol. Survey (new series). 9(2): 219 pp.

USDA NRCS. 2013. The PLANTS Database (http://plants.usda.gov, 15 March 2013). National Plant Data Center, Baton Rouge, LA 70874-4490 USA.

Wagner, D. L., D. F. Schweitzer, J. B. Sullivan, and R. C. Reardon. 2011. Owlet Caterpillars of Eastern North America (Lepidoptera: Noctuidae). Princeton University Press. 576 pp.

WeEd, A. S., AND R. A. CaSagrande. 2010. Biology and larval feeding impact of Hypena opulenta (Christoph) (Lepidoptera: Noctuidae): A potential biological control agent for Vincetoxicum nigrum and V. rossicum. Biol. Control. 53:214-222.

Weed, A. S., A. Gassmann, A. M. Leroux, and R. A. Casagrande. 2011. Performance of potential European biological control agents of Vincetoxicum spp. with notes on their distribution. J. Appl. Entomol. 135:700-713.

Submitted for publication 16 September 2013; revised and accepted 8 January 2014. 